\title{
COMPLIANCE MANAGEMENT UNDER THE CHEMICAL WEAPONS CONVENTION
}




\section{ACKNOWLEDGEMENTS}

Support from UNIDIR core funders provides the foundation for all of the Institute's activities. This project is supported by the Government of Norway.

\section{ABOUT UNIDIR}

UNIDIR is a voluntarily funded, autonomous institute within the United Nations. One of the few policy institutes worldwide focusing on disarmament, UNIDIR generates knowledge and promotes dialogue and action on disarmament and security. Based in Geneva, UNIDIR assists the international community to develop the practical, innovative ideas needed to find solutions to critical security problems.

\section{NOTE}

The designations employed and the presentation of the material in this publication do not imply the expression of any opinion whatsoever on the part of the Secretariat of the United Nations concerning the legal status of any country, territory, city or area, or of its authorities, or concerning the delimitation of its frontiers or boundaries. The views expressed in the publication are the sole responsibility of the individual authors. They do not necessary reflect the views or opinions of the United Nations, UNIDIR, its staff members or sponsors. 


\section{CONTENTS}

Summary

1 Introduction ... .

2 Legal and Political Aspects ....................................................................................................................................

2.1 Actors and Institutional Relationships......................................................................... 5

2.2 Mechanisms For Determining Compliance.....................................................................

2.3 CWC Fact-finding Mechanisms ....................................................................................

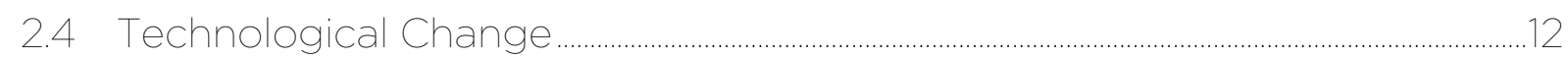

3 OPCW Compliance Management in Practice ............................................................................................ 13

3.1 Implementation Deficiencies after Entry Into Force of the CWC ........................14

3.2 Decision Making in the Executive Council.................................................................................17

3.3 Operational Aspects_General Issues and Routine Operations ..........................23

3.4 Operational Aspects_Ad-hoc Missions.........................................................................2 25

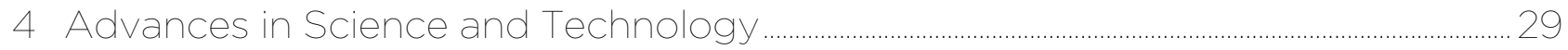

5 Compliance Enforcement and the CWC ....................................................................................... 31

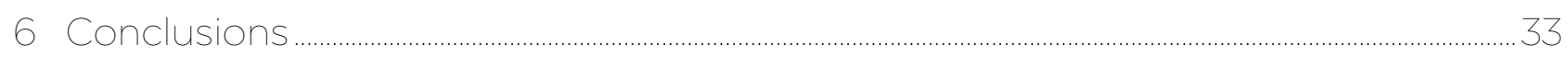

Annex 1 TAXONOMY OF CWC FACT-FINDING MECHANISMS............................................ 35

Annex 2 MAJOR OPCW COMPLIANCE ISSUES AND THEIR MANAGEMENT .............39

\section{LIST OF FIGURES}

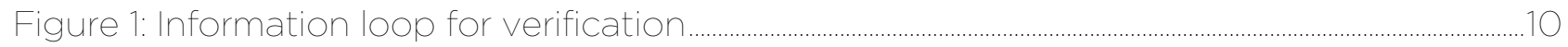

Figure 2: Breakdown of CWC fact-finding components................................................................11

Figure 3. Components of the CWC routine verification system............................................................24

Figure 4. Joint Mission operational lessons-learned ......................................................................2

Figure 5. Effects of advances in science and technology on CWC compliance............................29 


\section{ABOUT THE AUTHOR}

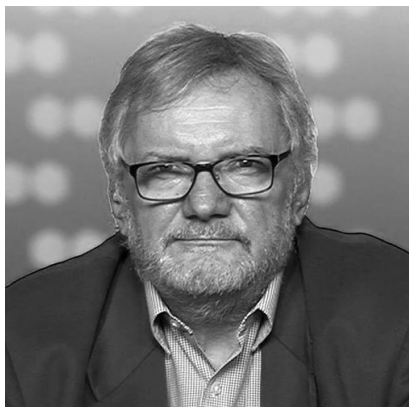

RALF TRAPP is an independent consultant working in the field of chemical and biological weapons arms control, safety and security. He is a chemist and toxicologist by training and participated as a technical adviser in the negotiations of the Chemical Weapons Convention during the 1980s and the final phases of negotiations in the Geneva Conference on Disarmament in 1992. After adoption of the Convention, he worked for 13 years in senior functions at the OPCW Technical Secretariat. Trapp contributed to the development of inspection procedures, the selection and training of OPCW inspectors, the training of personnel of National Authorities, and the design and implementation of international cooperation programmes, among others. He also was the Secretary of the OPCW Scientific Advisory Board from its inception until his departure from the OPCW in 2006. Since then, he has provided consulting services to the OPCW, the United Nations, the International Committee of the Red Cross, Spiez Laboratory, and several academic institutions in Europe and the United States, among others. 


\section{ABBREVIATIONS AND ACRONYMS}

\begin{tabular}{ll} 
CWC & Chemical Weapons Convention \\
\hline CW & chemical weapons \\
\hline FFM & Fact-finding Mission (OPCW) \\
\hline IIIM & International, Impartial and Independent Mechanism \\
\hline IIT & Investigation and Identification Team (OPCW) \\
\hline JIM & Joint Investigative Mechanism \\
\hline OPCW & Organization for the Prohibition of Chemical Weapons \\
\hline SAB & Scientific Advisory Board (OPCW) \\
\hline The Conference & Conference of the States Parties (OPCW)
\end{tabular}




\section{SUMMARY}

- The Chemical Weapons Convention (CWC) establishes a sophisticated, multifaceted legal and procedural framework for compliance assessments and decision-making in cases of non-compliance, with a clear delineation of the responsibilities of the different organs of the OPCW and an elaborate system of fact-finding (verification) procedures. Compliance management mechanisms include decision-making procedures as well as sanctions to re-establish compliance as soon as possible. There is also an option to take non-compliance issues of gravity to the UN Security Council and/or General Assembly.

- In practice, the Organization for the Prohibition of Chemical Weapons (OPCW) has successfully managed a range of situations in which States Parties had fallen short of implementing the Convention as required. Its responses have ranged from informal clarifications to technical assistance missions offered by the Technical Secretariat or implemented together with States Parties that offered such assistance, Executive Council decisions that set specific targets for States Parties to (re-)establish full compliance with specific provisions, as well as fact-finding, monitoring and reporting activities by the Technical Secretariat.

- These compliance management mechanisms worked well until the use of Sarin and chlorine in the Syrian armed conflict. Overlaid by geopolitical interests, chemical weapons use in Syria and Salisbury in the United Kingdom resulted in the polarization of the OPCW policymaking organs. This led to a growing controversy about the wisdom and legality of attribution investigations-with institutional, reputational, legal and political implications for the CWC and the OPCW that are yet to fully unfold. This paper considers some of these dimensions. 


\section{INTRODUCTION}

The Chemical Weapons Convention (CWC) is the primary global arms control and disarmament instrument in the field of chemical weapons. Earlier legal instruments, such as the 1925 Geneva Protocol, set out the basic humanitarian principles that prohibit the use of these weapons in armed conflict. They did not, however, ban the acquisition of chemical weapons, and reservations submitted to the 1925 Geneva Protocol largely rendered that instrument into a no-first-use treaty. At the same time, the prohibition of the use of chemical weapons in armed conflict forms part of customary international law.

Complementing and completing these humanitarian principles in international law, the CWC creates a global prohibition on the very possession of chemical weapons (CW). The CWC also aims at eliminating the means of acquiring them; it bans the development, production, stockpiling and use of chemical weapons and requires the destruction of any existing CW stockpiles as well as the elimination of facilities used previously for their production, within prescribed time frames and under strict international verification.

The CWC is complemented today by other multilateral instruments that aim to prevent the proliferation and use of chemical weapons, most notably Security Council resolution 1540 (2004). States also apply export control measures, as members of the Australia Group, of the European Union, or individually. In addition, the use of "asphyxiating, poisonous or other gases" has been included in the list of war crimes covered under the Rome Statutes of the International Criminal Court. ${ }^{1}$ Compliance with the international norms prohibiting chemical weapons, as well as with enforcement and responses to non-compliance, are therefore not limited to the mechanisms provided for under the CWC. The actions taken by States individually, by groups of States, and in the framework of the United Nations all affect compliance of States with the norm against chemical weapons, as well as the responses to acts committed by non-State actors related to the acquisition and use of toxic chemicals as weapons of war and terror.

This paper focuses on the compliance management mechanisms provided for under the CWC. It also examines practical experiences with compliance issues and how the Organisation for the Prohibition of Chemical Weapons (OPCW; the treaty organization established by the (WC) has managed compliance concerns as well as actual cases of noncompliance.

\footnotetext{
${ }^{1}$ United Nations. 1998. Article 8, "Rome Statute of the International Criminal Court". 17 July 1998. http://legal.un.org/icc/statute/99 corr/cstatute.htm - art.8
} 


\section{LEGAL AND POLITICAL ASPECTS}

The word 'compliance' appears 50 times in the text of the CWC. For a treaty the length and complexity of the CWC-24 articles, 3 Annexes (one of which breaks down into 11 separate parts), and a total of 766 paragraphs - this may seem like a small number. In fact, however, the CWC establishes an elaborate, multifaceted system of determining and managing compliance and dealing with cases of non-compliance. Its basic approach has been summarized thus: "ensure continued compliance of all parties, and encourage States Parties that have for whatever reason failed to comply fully with their obligations to take the measures necessary to return to full compliance without delay".2

\subsection{ACTORS AND INSTITUTIONAL RELATIONSHIPS}

Most prominent among the CWC provisions dealing with compliance are those contained in:

- article VIII, the statutes of the Organisation setting out, among others, the powers and functions of its different bodies;

- article IX, which deals with mechanisms to clarify compliance concerns and establish facts to assess whether non-compliance has occurred; and

- article XII, which deals with measures to redress a situation and to ensure compliance including sanctions.

The term 'compliance' also appears in article XIV, which deals with the settlement of disputes, but as a disclaimer to ensure that settlement of dispute procedures cannot be used to circumvent the provisions expressly set forth in the CWC to deal with non-compliance situations. Furthermore, there are articles IV, V and VI that deal, respectively, with declarations and verification of chemical weapons, chemical weapons production facilities, and legitimate chemical activities and facilities that may pose a risk to compliance with the CWC (such as certain production sites in the chemical industry). These articles have a direct bearing on compliance assessments as they provide baseline data for them.

The ultimate responsibility for managing compliance rests with the Conference of the States Parties (the Conference): article VIII of the CWC designates the Conference as the OPCW's principal organ that shall "oversee the implementation of this Convention, ... act in order to promote its object and purpose ... [and] review compliance ${ }^{\prime 3}$ with it. If a State Party fails to

\footnotetext{
${ }^{2}$ Krutzsch, Walter, Eric Myjer, and Ralf Trapp. 2014. "Part One Introduction and General Issues, The Chemical Weapons Convention-Objectives, Principles, and Implementation Practice". In The Chemical Weapons Convention: A Commentary, edited by Walter Krutzsch, Eric Myjer, and Ralf Trapp. p. 10.

${ }^{3}$ All quotes of Chemical Weapons Convention provisions are taken from the text of the "Convention on the Prohibition of the Development, Production, Stockpiling and Use of Chemical Weapons and on their Destruction" as published by the OPCW in 2005.
} 
take measures to re-establish full compliance, the Conference may limit certain rights and privileges of that State Party until it has taken measures to re-establish conformity with its obligations. ${ }^{4}$ In cases where serious damage to the objectives of the CWC may result from prohibited activities of a State Party, the Conference may recommend collective measures against that party. Such collective measures differ from sanctions applied by the Security Council, and in particular do not involve the use of force, which remains the prerogative of the Security Council under article 42 of the Charter of the United Nations. ${ }^{5}$ The Conference has the option, however, of taking compliance issues of particular gravity to the General Assembly or the Security Council. ${ }^{6}$

On a day-to-day basis, the task of overseeing compliance falls to the Executive Council. The Executive Council is tasked to promote the effective implementation of, and compliance with, the $\mathrm{CWC}_{i}^{7}$ to consider any issue or matter that affect the CWC and its implementation, including compliance concerns and cases of non-compliance; ${ }^{8}$ and to consult with the States Parties concerned and request the State Party causing compliance concerns to take measures to redress the situation within a specified time. ${ }^{9}$ Furthermore, the Executive Council can submit recommendations to the Conference regarding measures to be taken in case of non-compliance. ${ }^{10}$ This may include a recommendation to impose sanctions under article XII in case a State Party has not fulfilled the request by the Executive Council to reestablish full compliance within a prescribed time frame.

The Executive Council can also, in cases of particular gravity, take a compliance matter directly to the General Assembly or the Security Council. ${ }^{11}$

The Technical Secretariat's role is to assist Conference and Executive Council in the performance of their functions, and to implement the verification measures provided for by the CWC. ${ }^{12}$ The Technical Secretariat provides verified factual information to help the Conference and Executive Council, as well as States Parties individually, make their determinations about compliance, both in general terms related to how the treaty operates and with regard to specific compliance issues.

\footnotetext{
${ }^{4}$ CWC, art. XII.2.

${ }^{5}$ Dekker, Guido Den. 2014. "Art. XII Measures to Redress a Situation and to Ensure Compliance, Including Sanctions". In The Chemical Weapons Convention: A Commentary, edited by Walter Krutzsch, Eric Myjer, and Ralf Trapp. p. 373. ${ }^{6} \mathrm{CWC}$, art. XII.4.

${ }^{7}$ CWC, art. VIII.31.

${ }^{8} \mathrm{CWC}$, art. VIII.35.

${ }^{9} \mathrm{CWC}$, art. VIII.36.

10 lbid.

11 lbid.

${ }^{12}$ CWC, art. VIII.37.
} 
Three key conditions for the integrity of this process are:

1. That the Technical Secretariat staff meet the highest standards of efficiency, competence and integrity; that they are recruited on as wide a geographical basis as possible; that in the performance of their duties they do not seek or receive instructions from any government or other exterior source; and that they refrain from any action that might reflect on their positions as international officers responsible only to the Conference and the Executive Council. ${ }^{13}$

2. That inspectors and Technical Secretariat officials enjoy the privileges and immunities accorded to them under the CWC, to ensure the freedom of action and impartiality they require to conduct independent, technically competent and politically unbiased verification activities.

3. That the methods and tools used by the Technical Secretariat for verification purposes are scientifically sound, validated, and robust for use in the field.

In addition, the Scientific Advisory Board (SAB) provides information and assessments to the Director-General, and through them the OPCW policymaking organs and States Parties. This advice, too, supports the consideration of compliance issues (see also section 2.4 below).

\subsection{MECHANISMS FOR DETERMINING COMPLIANCE}

Determining CWC (non-)compliance involves several steps and actors. Marauhn observes that fact-finding is the first and decisive step in this process, leaving the politico-legal assessment to the political bodies of the OPCW ${ }^{14}$ and the Executive Council in particular. At the same time, Marauhn argues that although the evaluation of compliance or noncompliance is in the hands of the Executive Council, it is the responsibility of the inspection team, the Technical Secretariat, and above all the Director-General, to ensure that the factual findings are related to the specific non-compliance concern, but not necessarily to predetermine the outcome of the Executive Council's deliberations. ${ }^{15}$

Although the CWC ascribes responsibility to several organs of the OPCW with regard to key steps in the compliance management process it remains relatively vague on the question of who actually determines whether or not a given action was CWC compliant. It is clear from both the text of the CWC and the negotiation record that the determination of (non)compliance is seen as a political process in which the Executive Council plays a central role. Less apparent is where the balance lies between national determinations of compliance by States Parties individually, and a determination of (non-)compliance by the Executive Council. During the negotiations, some negotiators insisted that assessing compliance was

\footnotetext{
${ }^{13}$ CWC, art. VIII.44 and 46.

${ }^{14}$ Marauhn, Thilo. 2014. "Art. IX Consultations, Cooperation, and Fact-Finding". In The Chemical Weapons Convention: $A$ Commentary, edited by Walter Krutzsch, Eric Myjer, and Ralf Trapp. p. 314.

15 Ibid. p. 324.
} 
down to individual States Parties while others expected the Executive Council to make such determinations.

It can be inferred from the decision-making rules of the CWC, however, that the Executive Council has the power to make such determinations. While the Conference takes decisions on matters of substance by consensus and, only if that fails and after a cooling down period, may proceed to vote, ${ }^{16}$ the Executive Council is to take decisions on matters of substance by majority vote. (A majority requires two thirds of all the Executive Council's members except when voting on the conduct of a challenge inspection-blocking a challenge inspection would require a three-quarters majority). ${ }^{17,18}$ Furthermore, in the case of a challenge inspection, the CWC explicitly requires the Executive Council to review the final report of the inspection team, address any concerns as to whether non-compliance has occurred, and take measures to redress the situation and ensure compliance. ${ }^{19}$

The Executive Council's practice with regard to dealing with compliance issues is discussed in section 3.1 below. Nevertheless, it is important here to recall that the design assumption in the CWC is that these deliberations will be evidence-based and guided by the principle that the Executive Council shall promote the effective implementation of, and compliance with, the $C W C{ }^{20}$ This relationship between technical fact-finding and political decisionmaking is critical for the functioning of compliance assessments and management, as will be discussed next.

\subsection{CWC FACT-FINDING MECHANISMS}

Fact-finding is a key part of compliance management. It contrasts with other dispute settlement procedures in that it does not require an underlying dispute between certain parties (or a party and the OPCW). Moreover, fact-finding extends across reporting, monitoring, and assessment of compliance and includes outcomes and reactions in case of non-compliance. ${ }^{21}$

The CWC's fact-finding mechanisms can be broken down into consultation and clarification procedures, and verification measures implemented by the Technical Secretariat. Consultation and clarification are mechanisms used between States Parties, either on a bilateral basis ${ }^{22}$ or with the involvement of the Executive Council. The Executive Council may

\footnotetext{
${ }^{16} \mathrm{CWC}$, art. VIII.18. Also note that the rule stipulates a two-thirds majority of members present and voting, while in case of Council decisions, the majority rule relates to the full membership of the Council.

${ }^{17}$ CWC, art. VIII.29.

${ }^{18}$ This difference in voting rules has been explained by the role the Council plays with regard to considering cases of possible non-compliance: such situations require prompt decision-making and insistence on consensus could easily lead to decisions being blocked. See Krutzsch, Walter and Treasa Dunworth. 2014. "Art. VIII The Organization". In The Chemical Weapons Convention: A Commentary, edited by Walter Krutzsch, Eric Myjer, and Ralf Trapp. p. 275.

${ }^{19} \mathrm{CWC}$, art. IX.22-23.

${ }^{20} \mathrm{CWC}$, art. VIII.31.

${ }^{21}$ Marauhn, Thilo. 2014. "Art. IX Consultations, Cooperation, and Fact-Finding". In The Chemical Weapons Convention: $A$ Commentary, edited by Walter Krutzsch, Eric Myjer, and Ralf Trapp. p. 302.

${ }^{22}$ CWC, art. IX.1-2.
} 
simply be asked to provide information to clarify a non-compliance concern. ${ }^{23}$ Alternatively, it may be requested to play a role as interlocutor and mediator, which may involve the establishment of a group of experts to examine all information available on a noncompliance concern. ${ }^{24} \mathrm{~A}$ State Party may request the Executive Council to assist with the clarification of its own compliance in case that concerns have been raised about a situation that others have found to be ambiguous or causing concern. ${ }^{25}$

These provisions reflect a general trend in international law, including in arms control law, which sees consultation among the parties concerned as a core element in international security. It constitutes a general obligation on States, and at the same time may be considered an inherent element of the peaceful settlement of disputes. ${ }^{26}$

The CWC also provides for an elaborate system of international verification measures, however, including by on-site inspection. At the technical level, fact-finding requires 'translating' the question of whether a State Party was in (non-)compliance with treaty obligations-essentially a legal and political question-into a series of technical questions that can be answered by fact-finding methods. These technical methods must: ${ }^{27}$

- have a direct and unambiguous relationship with the underlying political/legal question (i.e., a technical finding will contribute to either substantiating or disproving a political conclusion that a party is in compliance with a particular obligation);

- rely on generally accepted scientific/technical methods that provide unambiguous technical findings (i.e., reproducible with known and accepted margins of measurement error); and

- assess these technical findings against generally accepted criteria that help translate them into conclusions that are meaningful in a political and legal context.

\footnotetext{
${ }^{23}$ CWC, art. IX.3.

${ }^{24}$ CWC, art. IX.4.

${ }^{25}$ CWC, art. IX.5.

${ }^{26}$ Marauhn, Thilo. 2014. "Art. IX Consultations, Cooperation, and Fact-Finding". In The Chemical Weapons Convention: $A$ Commentary, edited by Walter Krutzsch, Eric Myjer, and Ralf Trapp. p. 301.

${ }^{27}$ For a more exhaustive discussion see Trapp, R., and W. Rehak. 1988. "Principal Objectives of Verification Methods and Results". In Non-Production by Industry of Chemical-Warfare Agents: Technical Verification Under a Chemical Weapons Convention, edited by S. J. Lundin. SIPRI Chemical and Biological Warfare Studies Series No. 9. pp. 14-30.
} 


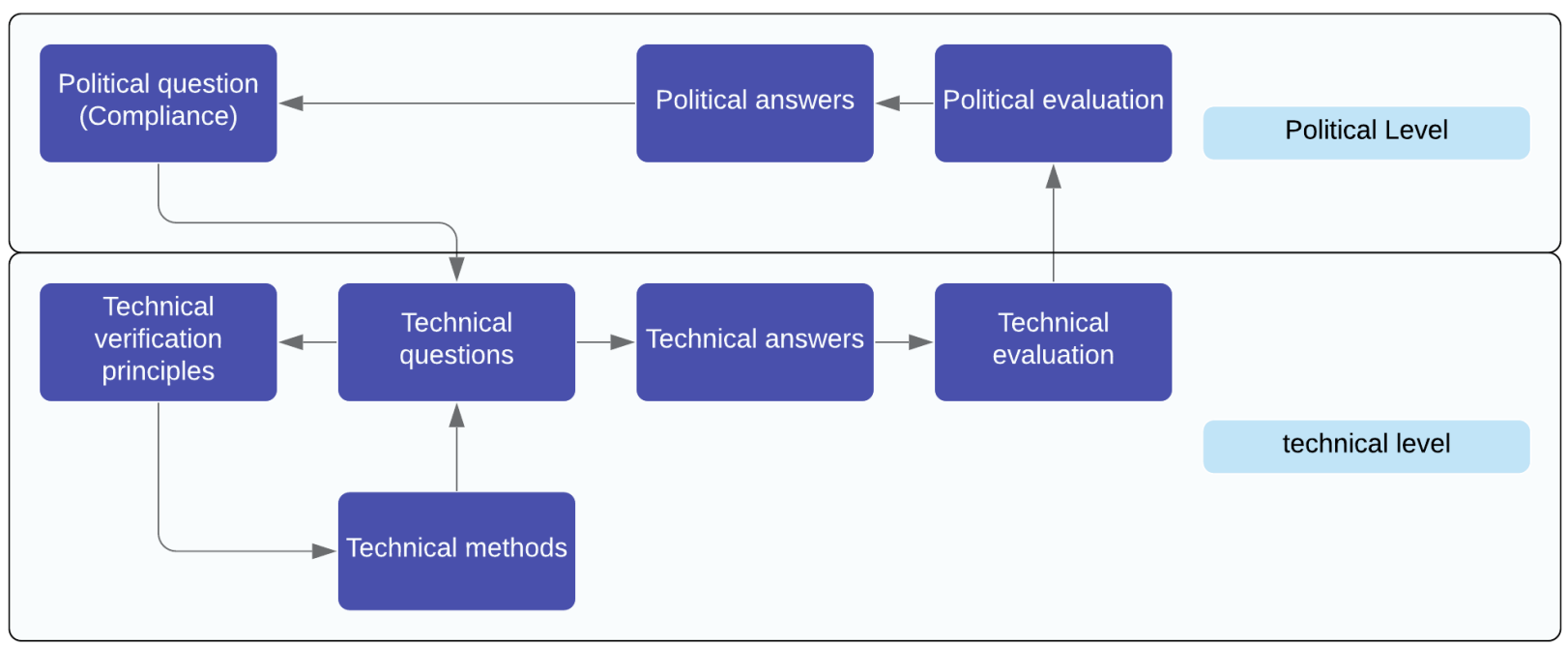

Information loop for verification

A schematic representation of the information loop so created is shown in figure 1. Such a verification system is relatively straightforward in cases where treaty-regulated items, such as missiles, are limited in number/diversity; can relatively easily be detected; access to raw materials or critical components can be controlled; and where, therefore, accountancy verification methodologies can be applied in a straightforward manner.

Chemistry does not lend itself easily to such an approach. In most cases, technical means of verification and fact-finding need to be based on strategies and tools more akin to risk assessment and statistically meaningful spot checks than to rigid accountancy controls, such as the system used in nuclear safeguarding. The exception is the systematic verification of the declaration, safeguarding and destruction of chemical weapons, as well as of critical ("specialized") CW production equipment.

Taxonomically, CWC fact-finding can be broken down into routine inspections, special (investigative) verification procedures (challenge inspection and investigations of alleged CW use), and clarification procedures. Figure 2 describes these (see also Annex 1). 


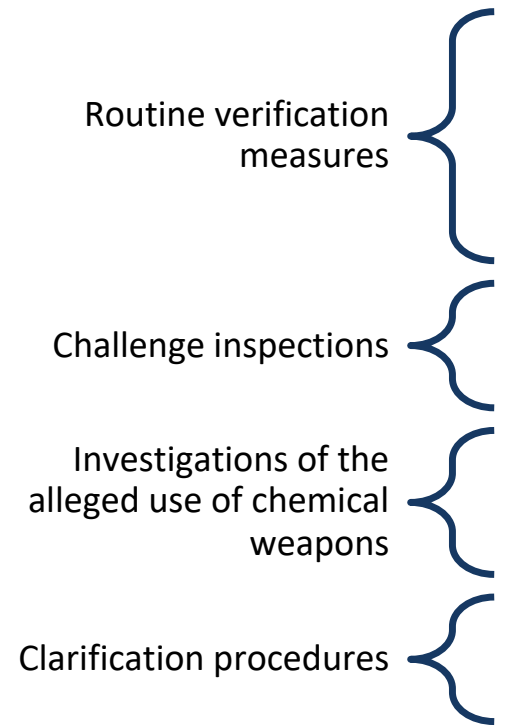

- confirm declared data

-create baselines for future verification activities and compliance assessments

-verify whether activities at declared facilities are in accordance with CWC requirements (consistency tests)

-inspect facilities/locations and gather factual information concerning particular non-compliance concerns

- verify whether chemical weapons have been used and if possible what their origin was

- resolve compliance issues among States Parties, either bilaterally or under the auspices of the Council

\section{Breakdown of CWC fact-finding components}

In technical terms, OPCW inspection teams visually inspect buildings, structures, equipment, etc.; conduct interviews; ${ }^{28}$ scrutinize documents and records; record photographic evidence; and collect samples for analysis on-site or off-site at Designated Laboratories of the OPCW. The operational freedom of the inspectors is framed by the provisions of the CWC itself, by OPCW guidelines and regulations, ${ }^{29}$ and by safety restrictions that apply at the inspected site. Escorts of the inspected State Party) may observe the inspection activities of OPCW inspection teams.

For the analysis of verification samples off-site, the OPCW has established a network of Designated Laboratories. Participating laboratories must be accredited for the types of analyses required, participate successfully and regularly in official OPCW proficiency tests, and comply with other requirements set by the OPCW regarding the positive identification of relevant chemicals, confidentiality regulations, chain of custody requirements and reporting standards. This network is managed by the OPCW Central Analytical Laboratory, which among others bears responsibility for the management of official OPCW proficiency tests. It also manages the transfer of samples collected by inspection teams and of control samples for analysis at Designated Laboratories. ${ }^{30}$

${ }^{28}$ These can be by collecting written as well as oral testimony, using 'walk-through talk-through' methods as well as structured and recorded interviews.

${ }^{29}$ These regulations include the inspection mandate setting out the scope and purposes of a particular inspection, safety regulations that apply at the inspected site and the safety requirements of the OPCW Health and Safety Policy and Regulations, any restrictions under the OPCW policy and regulations on the protection of confidentiality, and procedural guidelines and quality procedures set out in the OPCW Inspection Manual, in standard operating procedures and other quality assurance documents.

${ }^{30}$ Calibration of analytical instruments carried by inspection teams; oversight with regard to chain of custody; preparation of control samples and recoding of authentic samples before transfer to Designated Laboratories for analysis. 


\subsection{TECHNOLOGICAL CHANGE}

Compliance assessment and management are also affected by technological change. Several provisions of the CWC address challenges related to advances in science and technology. These provisions create a framework for States Parties and the Technical Secretariat to implement the CWC in ways that would promote cooperation among States Parties in the chemical field. They enable the monitoring and evaluation of advances in science and technology to adapt CWC implementation to changes in the implementation environment. They also help to identify new risks, such as novel types of agents or new CW manufacturing technologies, and opportunities, including for enhanced international cooperation, improving protection against chemical weapons, and new inspection methods and equipment.

The SAB supports these evaluations and reaches back into the global scientific community to seek advice, monitor relevant developments, and identify new challenges and opportunities. It reports directly to the Director-General who in turn advises States Parties and the OPCW policymaking organs, and the Director-General also uses SAB guidance in managing the work of the Technical Secretariat.

A fundamental principle of the CWC that has been built into a number of interlocking provisions is the so-called "General Purpose Criterion". ${ }^{31}$ One of the key roles of this criterion is to make the CWC 'future proof'. The General Purpose Criterion's prohibitions must apply to any chemical weapon no matter what chemical agent (or precursor) it employs, and including chemicals that have yet to be synthesized or discovered. The SAB plays an important role in assessing new scientific advances in the light of this principle.

All these mechanisms and institutional arrangements support the OPCW's compliance management system. This is true both in terms of helping the OPCW identify scientific and technological challenges that might undermine compliance and by helping the Technical Secretariat reap the opportunities of scientific and technological progress for improving its fact-finding and analytical capabilities.

${ }^{31}$ Paragraph 1(a) of article II defines chemical weapons as toxic chemicals and their precursors, except where intended for purposes not prohibited under this Convention, as long as the types and quantities are consistent with such purposes (emphasis added). This legal construct makes intent as well as consistency of the types and amounts of a chemical with that intended purpose the test criteria to decide whether a toxic or precursor chemical qualifies as a chemical weapon. The "purposes not prohibited by this Convention" are explicitly listed in paragraph 9 of article II. In contrast to this broad scope of the prohibitions, the routine verification system has a more limited focus, using the Schedules of Chemicals as the means to identify chemicals for the application of verification measures (Annex on Chemicals, Section B chapeau). But implementation measures by States Parties nevertheless must ensure that "toxic chemicals and their precursors are only developed, produced, otherwise acquired, retained, transferred, or used ... for purposes not prohibited by this Convention" (paragraph 2 of article $\mathrm{VI}$ ). While the specific verification provisions in parts $\mathrm{VI}$ through VIII of the Verification Annex are governed by the Schedules, the general obligation on States Parties not to acquire or use chemical weapons is not. This legal construction ensures that any toxic or precursor chemical that was developed, produced, otherwise acquired, stockpiled, transferred or used with chemical weapons purposes in mind by necessity qualifies as a chemical weapon, whether listed in any of the Schedules of the CWC or not. 


\section{OPCW COMPLIANCE MANAGEMENT IN PRACTICE}

Managing compliance has been on the OPCW's agenda since the very start of its operations, even though the terms 'compliance' and 'non-compliance' were rarely used in official OPCW documents during the initial CWC implementation phase.

The CWC itself does not establish a hierarchy of severity of different forms of noncompliance, nor does it distinguish between technical/institutional and material noncompliance. ${ }^{32}$ It therefore leaves it to States Parties to decide how to approach a situation of presumed non-compliance with certain treaty provisions and to weigh the political and other consequences of using any of the formal compliance procedures of the CWC, or of relying on informal measures, or of 'packaging' compliance concerns into a broader context of consultation and cooperation among States Parties and within the OPCW.

Ensuring compliance is, of course, primarily the responsibility of the States Parties. Their national authorities are key to this process. They need to be equipped with adequate legal authority, institutional strength and technical competence to manage the internal processes of a State Party to ensure compliance.

The mechanisms that the OPCW uses to assess and promote compliance have evolved over time. The States Parties, as well as the Technical Secretariat, have responded to changes in the implementation environment and adopted political approaches. They have also adapted technical concepts to foster compliance and assist States Parties that had encountered problems with the full implementation of CWC requirements.

Many States Parties had underestimated the amount of regulatory and administrative work and the resources that implementing the $\mathrm{CWC}$ required. Some had altogether neglected the need to take action beyond submitting their ratification instrument.

Many cases of non-compliance with CWC administrative requirements were therefore treated as implementation deficiencies: the OPCW was keen to avoid using the label of noncompliance so as not to create political animosity. Instead, the objective was to alert States Parties to such deficiencies, provide guidance on what needed to be done, and mobilize

\footnotetext{
${ }^{32}$ For example: a citizen of a State Party commits a criminal act by using a chemical weapon while taking part in an insurgency abroad. What does that imply for compliance by the State Party? Did the State Party itself violate the prohibition to use CW? Did it fail to enact or enforce the prohibition of CW use by its citizens? Did it fail to extend this prohibition to its subjects abroad? Was it simply not able to enforce the prohibition as long as the individual remained abroad? And finally: are there differences in the level of compliance of said State Party with its obligations under the CWC depending on how the issue is approached? The CWC does not make such distinctions but, obviously, the State's responsibility under international law would not be the same as if it itself had instigated, or conducted, the use of the chemical weapon.
} 
assistance to States Parties that lacked expertise or capacity to implement CWC requirements.

A central element of how the OPCW manages compliance in practice is this division of labour between National Authorities, which oversee CWC implementation at the domestic level, and the Technical Secretariat. The inclusion of a dedicated implementation support programme in the OPCW programme and budget structure is an indicator that this support for national implementation, and the synergy between the work of National Authorities and the Technical Secretariat, are seen as strategic objectives for the CWC's effective functioning. ${ }^{33}$

But there have also been cases of material non-compliance, and these turned out to more be challenging to manage, controversial in terms of decision-making, and at times divisive.

Annex 2 gives an overview of major compliance issues that the OPCW has been managing since the entry into force of the CWC. In the following sections, some key institutional, procedural and operational issues are discussed in more detail.

\subsection{IMPLEMENTATION DEFICIENCIES AFTER ENTRY INTO FORCE OF THE CWC}

Right from the beginning of CWC operations, the challenge of incomplete or altogether lacking compliance with key implementation requirements of the CWC had to be managed. Examples included the delay of the United States to enact its implementing legislation and submit its industry declaration under article VI; the failure of many States Parties to submit their initial declarations, ${ }^{34}$ or to designate or establish a National Authority; ${ }^{35}$ and the failure of many States to make the necessary administrative arrangements to enable the conduct of OPCW inspections in accordance with the CWC. ${ }^{36}$ The Technical Secretariat responded to these deficiencies with targeted efforts to provide technical, legal and political assistance, and some were remedied during the early years of CWC operation. ${ }^{37}$

\footnotetext{
${ }^{33}$ For a recent summary of implementation support activities implemented by the OPCW, see OPCW Technical Secretariat. 2019. "Update on events organised by the Technical Secretariat in the area of international cooperation and assistance, January-April 2019", S/1761/2019, 12 June 2019.

${ }^{34}$ At the end of 1999, almost one third of initial declarations remained still outstanding, often due to delays in national preparations, a lack of awareness of obligations States Parties needed to meet at the outset of treaty operations, or inadequate technical capacity or legal frameworks. See OPCW Technical Secretariat. 2003. "Technical Secretariat Background Paper: Consolidated Unclassified Verification Implementation Report (April 1997-31 December 2002)". RC-1/S/6, 25 April 2003. para. 2.2.

${ }^{35}$ For details see OPCW Technical Secretariat. 2003. "Implementation Support". RC-1/S/3, 23 April 2003.

36 OPCW Technical Secretariat. 2003. "Technical Secretariat Background Paper on the Conduct of Inspections under the Chemical Weapons Convention and Related Issues". RC-1/S/1, 17 April 2003.

${ }^{37}$ Examples included a dedicated campaign to visit States Parties to encourage and where possible collect on the spot their initial declarations; technical assistance and evaluation visits to provide support to States Parties with their declarations; the establishment of the Implementation Support Branch build capacity in States Parties; and regular reporting of the status of CWC implementation to the Council and the Conference. See the OPCW Technical Secretariat. 2003. "Technical Secretariat Background Paper: Consolidated Unclassified Verification Implementation
} 
The Technical Secretariat prepared a comprehensive analysis of the implementation status in all major domains for the First Review Conference in 2003. ${ }^{38,39}$ After noting "with particular concern" that a large number of States Parties had not fulfilled certain basic obligations associated with national implementation, the First Review Conference agreed on a catalogue of measures that States Parties needed to take to ensure full national implementation. ${ }^{40}$

The First Review Conference also drew attention to the many 'unresolved issues' that had been left behind by the Preparatory Commission, some of which affected national decisions about whether and how to declare particular facilities. ${ }^{41}$ Different national interpretations of CWC provisions had led to uneven implementation in such areas as opening parts of the chemical industry to inspections, or declaring aspects of past CW activities such as CW development facilities. The First Review Conference urged the Executive Council to speedily conclude these unresolved issues, ${ }^{42}$ a task that has yet to be completed at the time of writing.

One of the specific outcomes of the First Review Conference was a Plan of Action to improve national implementation. ${ }^{43}$ It set a two-year time frame for States Parties to get their houses in order, with particular emphasis on establishing fully functioning National Authorities and enacting legislation to implement the CWC. This time frame turned out to be too short. Also, many new States joining the CWC lacked adequate legal, administrative and institutional systems to fully implement the treaty. As a consequence, the Tenth Session of the Conference in 2005 decided on follow-up measures to the Action Plan. ${ }^{44}$

Report (April 1997-31 December 2002)". RC-1/S/6, 25 April 2003. see also Tabassi, Lisa, and Anand Dhavle. 2014. "Art. VII National Implementation Measures". In The Chemical Weapons Convention: A Commentary, edited by Walter Krutzsch, Eric Myjer, and Ralf Trapp. pp. 211-21.

38 OPCW. 2003. "Background Paper on the Conduct of Inspections under the Chemical Weapons Convention and related issues". RC-1/S/1, 17 April 2003; OPCW Technical Secretariat. 2003. "Implementation Support". RC-1/S/3, 23 April 2003; OPCW Technical Secretariat. 2003. "Technical Secretariat Background Paper on Assistance and Protection Programmes". RC-1/S/4, 24 April 2003; OPCW Technical Secretariat. 2003. "Technical Secretariat Background Paper: Consolidated Unclassified Verification Implementation Report (April 1997-31 December 2002)". RC-1/S/6, 25 April 2003.

${ }^{39}$ OPCW Director General. 2003. "Note by the Director-General to the First Review Conference". RC-1/DG.1, 17 April 2003.

40 This included legislation, establishing functioning and fully authorized National Authorities, implementing transfer controls for scheduled chemicals, and certain measures required to implement articles X and XI. For details see OPCW. 2003. "Report of the First Review Conference". RC-1/5, 9 May 2003.

${ }^{41}$ Examples included different interpretations of the definitions of former CW development facilities, and of other chemical production facilities in the chemical industry. See section 4 of OPCW. 1997. "Final Report of the Preparatory Commission". PC-XVI/37, 15 April 1997. pp. 37-53. After entry into force, a facilitation process had been designed under the overall leadership of the Chairman of the Committee of the Whole of the First Session of the Conference of States Parties. Under his direction, facilitators attempted to resolve some of these issues. Eventually, the remaining issues were handed over the Council for resolution.

42 OPCW. 2003. "Report of the First Review Conference". RC-1/5, 9 May 2003. para. 7.123.

${ }^{43}$ OPCW. 2003. "Plan of Action on the Implementation of Article VII Obligations". C-8/Dec.16, 24 October 2003.

44 Tabassi, Lisa, and Anand Dhavle. 2014. "Art. VII National Implementation Measures". In The Chemical Weapons Convention: A Commentary, edited by Walter Krutzsch, Eric Myjer, and Ralf Trapp. pp. 214-5. 
The Action Plan set specific targets for States Parties and provided assistance through the Technical Secretariat as well as States Parties that were able to offer assistance. Its success was not immediately visible, but over time significant, measurable progress was made in the quality of national implementation.

At the Second Review Conference, the OPCW narrowed the focus of implementation support to concentrate on tailor-made, results-based measures. ${ }^{45}$ Several new initiatives were started, such as internships for legislation drafters and outreach to parliamentarians. The Third Review Conference in 2013 noted that 97 States Parties still needed to adopt the necessary measures to fully implement their CWC obligations. ${ }^{46}$ The Chair of the Fourth Review Conference again "highlighted the need ... to filling gaps in national implementation, and to ensuring that national implementation measures are consistent with the provisions of the Convention" ${ }^{47}$ and listed a total of nine measures that States Parties and the Technical Secretariat should take to improve the situation. ${ }^{48}$

The article VII Action Plan demonstrates the fundamentally cooperative approach of compliance management under the CWC. ${ }^{49}$ Such a cooperative, enabling approach is time and resource intensive, but it creates ownership and capacity in the States Parties and leads to long-term commitments to implement and enforce the CWC norms and requirements. ${ }^{50}$

This differs from the response of the OPCW to compliance concerns that directly concern basic treaty undertakings (eliminating chemical weapons, preventing their re-emergence, or using toxic chemicals in armed conflict). Such non-compliance situations require immediate attention and swift response. Given that compliance management is essentially a political process, the role of the Executive Council and the manner in which it takes decisions are crucial.

45 Ibid. p. 219.

${ }^{46}$ OPCW. 2013. "Report of the Third Special Session of the Conference of the States Parties to Review the Operation of the Chemical Weapons Convention". RC-3/, 19 April 2013. para 9.10.

47 The Fourth Review Conference failed to adopt a Final Document. Its results were reflected in a Chairman's paper. OPCW. 2018. "Chairperson's Report of the Proceedings of the Fourth Special Session of the Conference of the States Parties to Review the Operation of the Chemical Weapons". RC-4/3/Rev.1, 30 November 2018. para. 9.63.

${ }^{48}$ Ibid. para. 9.65.

${ }^{49}$ Other examples included the initiative of the Technical Secretariat to encourage initial declaration submissions under article III, the Technical Secretariat project to help States Parties with identifying declarable chemical industry facilities based on open source analysis, technical assistance visits to States Parties to provide technical assistance and evaluation with regard to how certain facilities or objects should be declared, the development of tools such as questionnaires and a legislation tool kit, the setting up of expert networks to support States Parties in such areas as protection against toxic chemicals, and capacity-building measures in key technical areas (chemical analysis, regulatory compliance measures in the chemical industry, inspection escorting, identification of chemical industry facilities, declaration data submission in electronic or hardcopy format, and many more).

${ }^{50}$ For a detailed discussion of this point including of three cases of national prosecutions as well as issues related to cooperation between States Parties in investigations and prosecutions, see Tabassi, Lisa, and Anand Dhavle. 2014. "Art. VII National Implementation Measures". In The Chemical Weapons Convention: A Commentary, edited by Walter Krutzsch, Eric Myjer, and Ralf Trapp. pp. 222-9. 


\subsection{DECISION MAKING IN THE EXECUTIVE COUNCIL}

Consensus culture: Executive Council decision-making during the first 15 years of CWC operations was essentially by consensus, reflecting the practice adopted by many other multilateral bodies. It also recognized that the Preparatory Commission had left behind more than 60 issues to resolve. Many of these required formal Conference decisions, and the Executive Council adopted a consensual approach to resolving them. ${ }^{51}$

As a consequence, Executive Council decisions were delayed or avoided whenever consensus could not be achieved. While this maintained broad support of the OPCW membership, it was not an effective approach to resolving urgent matters requiring decisive action. Some observers characterized this as a "culture of deferral".$^{52}$ Others remarked that it "contributed to the Council's lack of action to fulfil its functions and exert its powers in situations of conflict or uncertainty". ${ }^{53}$ Over time, this approach also led to some watering down of CWC provisions. ${ }^{54}$

Examples of successful decision-making: Nevertheless, decisions concerning compliance issues were taken, albeit with significant delay at times. A key example was the decision on the destruction of chemical weapons beyond the final CWC extended deadline. ${ }^{55}$ This decision was developed in anticipation of certain possessor States Parties not being able to meet the final extended CW destruction deadline, in an intensive negotiation process that took more than a year. ${ }^{56}$ It has been characterized as an exemplary example for managing compliance cases related to article I of the Convention. ${ }^{57,58}$

${ }^{51}$ Also, some key States were not among the initial States Parties (including the Russian Federation, the Islamic Republic of Iran and Pakistan) and decision-making by voting might have complicated their eventual ratification of the CWC.

52 Kelle, Alexander. 2002. "The First CWC Review Conference: Taking Stock and Paving the Way Ahead". Disarmament Forum. UNIDIR. p. 7.

${ }^{53}$ Walter Krutzsch, and Treasa Dunworth. 2014. "Art. VIII The Organization". In The Chemical Weapons Convention: $A$ Commentary, edited by Walter Krutzsch, Eric Myjer, and Ralf Trapp. p. 276.

${ }^{54}$ Myjer, Eric P. J. (ed.). 2001. Issues of Arms Control Law and the Chemical Weapons Convention: Obligations Inter Se and Supervisory Mechanisms. pp. 90-91.

${ }^{55}$ Article IV, para. 6, requires each possessor State Party to complete the destruction of all its chemical weapons no later than 10 years after the entry into force of the CWC (this is a fixed date: 29 April 2007). This deadline could be extended by the Conference following a recommendation by the Council, but in accordance with Verification Annex, part IV(A), para. 26, in no case beyond 15 years after entry into force (i.e., 29 April 2012). When it became apparent that some possessor States Parties, and in particular the Russian Federation and the United States, would not meet this final deadline, the question arose how the OPCW would manage a situation of imminent and prolonged noncompliance with a key obligation directly related to the object and purpose of the CWC.

${ }^{56}$ OPCW Conference of the States Parties. 2011. "Decision-Final Extended Deadline of 29 April 2012". C-16/Dec.11. 1 December 2011.

${ }^{57}$ Krutzsch, Walter, and Treasa Dunworth. 2014. "Art. VIII The Organization". In The Chemical Weapons Convention: $A$ Commentary, edited by Walter Krutzsch, Eric Myjer, and Ralf Trapp. p. 262. For a more detailed discussion see Trapp, Ralf, and Paul Walker. 2014. "Article IV: Chemical Weapons", In The Chemical Weapons Convention: A Commentary, edited by Walter Krutzsch, Eric Myjer, and Ralf Trapp. pp. 126-133.

${ }^{58}$ Key elements of this decision were: No action should be undertaken that would undermine the commitment of States Parties, or CWC provisions; the destruction of any remaining chemical weapons was to continue in accordance with the provisions of the CWC, and the additional requirements of the decision; the Council should meet immediately after the deadline had passed, to assess the situation; the Director-General should report to Council if certain article I 
The decision closely followed the logic and intent of article VIII, paragraph 36. It is worth noting that the text of the decision uses the term 'compliance' only twice-in both cases in its preamble. But the intention was clear: to create a political environment and practical framework that would enable re-establishment of full compliance at an early date, ensuring full cooperation of the possessor States concerned while respecting the non-compliance concerns of other States and preserving the integrity of the regime. The decision also avoided other complications. For example, an alternative could have been an amendment of the CWC. ${ }^{59}$ Such an approach would have 'normalized' the non-compliance situation rather than allowing the Executive Council to apply a series of specific measures aimed at re-establishing compliance under conditions acceptable to all parties. Furthermore, reference to article XII was avoided-this would not have been helpful in maintaining a climate of full cooperation by the possessor States Parties that were experiencing the delays.

A similar pragmatism was shown in cases when the OPCW had to interpret what was seen by some as conflicting rules within the CWC, such as a potential conflict between the prohibition to transfer chemical weapons and the requirement to destroy chemical weapons. $^{60}$

Coercive compliance: Compliance management changes in nature when States accede to a treaty under external pressure rather than as the result of a conscious decision about the long-term advantages and disadvantages of disarmament. The CWC example is the Syrian Arab Republic.

The Syrian Arab Republic acceded to the CWC in September 2013, ${ }^{61}$ after an investigation had confirmed the use of Sarin against the densely populated quarters of Ghouta in August 2013. Western States threatened military strikes, prevented by a last-minute deal between

undertakings had not been fulfilled; adoption of a set of measures by the possessor States Parties to complete destruction operations as early as possible (including setting a timeline for completion), and of verification measures to be applied by the Technical Secretariat; regular reporting by these States Parties and the Director-General and reviews of the situation by the Conference; regular Council visits to review the implementation of the destruction programmes. See OPCW Conference of the States Parties. 2011. "Decision—Final Extended Deadline of 29 April 2012 ". C-16/Dec.11. 1 December 2011.

${ }^{59}$ For more detail see Trapp, Ralf, and Paul Walker. 2014. "Article IV: Chemical Weapons", In The Chemical Weapons Convention: A Commentary, edited by Walter Krutzsch, Eric Myjer, and Ralf Trapp. pp. 130-2.

60 This issue came up when Austria discovered a small number of chemical weapons and needed to move them to Germany for destruction as it lacked a destruction facility; during the removal of chemical weapons precursors and related chemicals from Syria for destruction abroad; and during the removal of Category 2 chemical weapons from Libya for destruction in Germany. For details see, respectively, Joint National Paper by Austria and Germany, "Destruction of old chemical weapons found in Austria". OPCW document EC-48/Nat.5. 12 March 2007; The Council approved the transfer subject to a number of understandings and conditions; see para. 5.25 of OPCW. 2007. "The Report of the 48th Session of the Executive Council". EC-48/3 16 March 2007; and OPCW. 2013. "Destruction of Syrian Chemical Weapons". EC-M-33/DEC.1, 27 September 2013. This decision was 'harvested' by Security Council resolution 2118/ (2013), taken immediately after its adoption and under chapter VII; note that article 103 of the Charter of the United Nations stipulates that obligations under the Charter, which include binding Security Council resolutions, take precedence over any other treaty obligations.

${ }^{61}$ The Syrian Arab Republic notified the Secretary-General of its intention to apply the CWC provisionally; it deposited its instrument of accession on 14 September 2013 and became a State Party on 14 October of the same year. 
the Russian Federation and the United States. Instead, the two States agreed a framework for the elimination of Syrian chemical weapons. The Syrian Arab Republic joined the CWC, and the Security Council established a Joint Mission of the OPCW and the United Nations to eliminate Syrian chemical weapons. ${ }^{62}$ United in its desire to take chemical weapons out of Syrian territory to prevent any further CW use in what was becoming an increasingly violent armed conflict with regional dimensions, the Executive Council agreed a programme to transform the Russian-US framework into a multilateral agreement. ${ }^{63}$

The OPCW-UN Joint Mission worked for approximately one year and successfully eliminated the declared Syrian chemical weapons stockpile. It also functionally disabled and partly destroyed the Syrian Arab Republic's declared CW production facilities. This task was subsequently completed under an OPCW mandate.

A lessons-learned exercise in 2015 looked at a range of factors that contributed to the success of this first OPCW mission in the Syrian Arab Republic. ${ }^{64}$ Among its findings:

[In] the end, the political support for the Syria mission, which was forged by Security Council resolution 2118 (2013), was sufficiently constant to avoid legal challenges. At the same time, it signalled a shift from a narrow reading of the Convention towards one that understands the Convention as providing a pragmatic regulatory and policy framework that can be adapted by Member States to open up legal and operational space for effective disarmament and verification under unforeseen circumstances. ${ }^{65}$

However, by 2014, new reports about the use of toxic chemicals in the Syrian conflict emerged. There was also increasing concern about the completeness of the Syrian CW declaration. To address these matters, the Director-General, after informal consultations with key States Parties, established two new ad hoc mechanisms: the Fact-finding Mission (FFM) and the Declaration Assessment Team. Both were agreed bilaterally with the government of Syria and subsequently endorsed by the Executive Council. The OPCW also established a reporting line to the Security Council.

Both mechanisms were set up despite the fact that the CWC itself contains provisions for fact-finding in relation to such non-compliance concerns; that is, challenge inspection and investigation of alleged use. Yet States Parties were reluctant to invoke them in the

\footnotetext{
${ }^{62}$ For a discussion of some of the legal ramifications of this development, see Trapp, Ralf. 2017. "The Use of Chemical Weapons in Syria: Implications and Consequences". In One Hundred Years of Chemical Warfare: Research, Deployment, Consequences, pp. 363-75. https://doi.org/10.1007/978-3-319-51664-6 19. For a discussion of some of the legal implications see Krutzsch, Walter, Eric Myjer, and Ralf Trapp. 2014. "Issues raised by the accession of Syria to the Chemical Weapons Convention". In The Chemical Weapons Convention: A Commentary, edited by Walter Krutzsch, Eric Myjer, and Ralf Trapp. pp. 689-701.

63 OPCW. 2013. "Destruction of Syrian Chemical Weapons". EC-M-33/DEC.1, 27 September 2013.

64 Trapp, Ralf. 2015. "Lessons Learned from the OPCW Mission in Syria". https://www.opcw.org/sites/default/files/documents/PDF/Lessons learned from the OPCW Mission in Syria.pdf.

65 lbid. para. 46.
} 
circumstances-neither mechanism had ever been used before. ${ }^{66}$ Moreover, it seems that States Parties feared that invoking them might carry excessive political risks; a failure to properly implement such formal CWC investigations could also have damaged the mechanisms themselves.

Furthermore, in its decision about the elimination of Syrian chemical weapons, the Executive Council had instructed the Technical Secretariat to "inspect as soon as possible any other site identified by a State Party as having been involved in the Syrian chemical weapons programme, unless deemed unwarranted by the Director-General, or the matter resolved through the process of consultations and cooperation" ${ }^{67}$ This provision goes well beyond the normal challenge inspection procedure of the CWC. The Executive Council has no option to stop such an investigation.

This mechanism, too, was never invoked. Instead, the FFM and the Declaration Assessment Team were set up with reference to the general authority of the Director-General under the CWC, and by consent of the Syrian government. This demonstrated the ability of the OPCW to adapt CWC mechanisms to unforeseen circumstances. However, it also carried a penalty: both mechanisms had no terms of reference negotiated among States Parties or by the Executive Council - they depended on what the Syrian and later also the Russian Federation governments were willing to support. This made them vulnerable to accusations of political bias as well as lack of procedural and technical integrity.

From constructive pragmatism to attribution: Constructive pragmatism in OPCW decision-making on compliance was possible as long as unity prevailed within the Executive Council, using as reference point the fundamental objectives of the CWC "to exclude completely the possibility of the use of chemical weapons". ${ }^{68}$ Executive Council unity began to wither after the Security Council established the Joint Investigative Mechanism (JIM) to attribute responsibility for the chemical weapons uses in the Syrian conflict. ${ }^{69}$ As the JIM began to attribute responsibility for some of the chemical weapons attacks to the Syrian armed forces, compliance management became problematic. ${ }^{70}$ In New York, the Security Council failed to extend the mandate of the JIM because of multiple vetoes by the Russian Federation; in The Hague, the Executive Council was presented with fundamentally diverging draft decisions on how to proceed in light of the JIM report. A draft decision sponsored by the Islamic Republic of Iran and the Russian Federation effectively questioned the

\footnotetext{
${ }^{66}$ The investigation of the use of chemical weapons conducted during 2013 was conducted under the Secretary-General's Mechanism; OPCW inspectors supported that investigation as is anticipated in para. 27 of part XI of the CWC Verification Annex but, both legally and institutionally, the investigation was in the hands of the Secretary-General.

${ }^{67}$ OPCW. 2013. "Destruction of Syrian Chemical Weapons". EC-M-33/DEC.1, 27 September 2013. para. 2(d).

${ }^{68}$ CWC preamble. para. 6.

${ }^{69}$ To "identify individuals, entities, groups, or governments who were perpetrators, organisers, sponsors or otherwise involved in the use of chemicals as weapons in Syria"; see Security Council resolution RES/2235 (2015), para 5.

${ }^{70}$ See the seventh and last report of the JIM issued on 26 October 2017 under letter of the Secretary-General: Organization for the Prohibition of Chemical Weapons-United Nations Joint Investigative Mechanism. 2017. "Seventh report of the Organisation for the Prohibition of Chemical Weapons-United Nations Joint Investigative Mechanism". S/2017/904, 26 October 2017.
} 
investigation results related to the attack on Khan Shaykhun and the integrity of the investigations conducted by the FFM and the JIM, while a draft decision sponsored by Colombia, Estonia, Saudi Arabia and the United States attributed responsibility for the attack squarely to the Syrian government, concluded that this demonstrated that the Syrian declaration had been incomplete, and set out a series of steps required to remedy the noncompliance situation. ${ }^{71}$ The Executive Council failed to agree on a common position or action, and the report of the subsequent annual Session of the Conference remained silent on the matter.

The year 2018 saw a deepening of the divide in the OPCW on the Syrian issue. The nonextension of the JIM mandate had left a void with regard to investigating the responsibility for cases of chemical weapons use in the Syrian conflict. There remains a mechanism established in 2017 by the General Assembly - the International, Impartial and Independent Mechanism (IIIM) ${ }^{72}$ - but the mechanism is still being built up. Also, the IIIM's focus is on personal culpability rather than State non-compliance.

In January 2018, France launched a partnership against impunity for the use of chemical weapons. By August 2019, 41 States were participating, sharing common commitments to "Gather, compile and retain all available information on those who use chemical weapons" and "Publish the names of all individuals, entities, groups or governments which have been subject to sanctions, via a dedicated online platform". ${ }^{33}$ However, an international attribution mechanism comparable to the JIM no longer existed. This, together with the Novichok

${ }^{71}$ See the documents of the 56th Meeting of the Executive Council, in particular the national statements of Australia. 2018. "Statement by H.E. Ambassador Dr Brett Mason Permanent Representative of Australia to the OPCW at the Fifty-Sixth Meeting of the Executive Council". EC-M-56/NAT.6, 9 November 2017; The Russian Federation. 2017. "Statement by H.E. Ambassador A.V. Shulgin Permanent Representative of the Russian Federation to the OPCW at the Fifty-Sixth Meeting of the Executive Council under Agenda item 4". EC-M-56/NAT.7, 9 November 2017; United Kingdom. 2017. "Statement by H.E. Ambassador Peter Wilson, Permanent Representative of the United Kingdom of Great Britain and Northern Ireland at the Fifty-Sixth Meeting of the Executive Council". 9 November 2017.

https://www.opcw.org/sites/default/files/documents/EC/M-56/en/UK Delegation to the OPCW page 2.pdf; United States. 2017. "Statement by H.E. Kenneth D. Ward Permanent Representative of the United States of America to the OPCW at the Fifty-Sixth Meeting of the Executive Council EC-M-56". 9 November 2017.

https://www.opcw.org/sites/default/files/documents/EC/M-

56/en/Statement_by_H.E. Kenneth_D. Ward_Permanent Representative of the USA to the OPCW_page_2.pdf

72 Its full name is International, Impartial and Independent Mechanism to Assist in the Investigation and Prosecution of Persons Responsible for the Most Serious Crimes under International Law Committed in the Syrian Arab Republic since March 2011. For the decision to establish the IIIM, see General Assembly. 2017. "International, Impartial and Independent Mechanism to Assist in the Investigation and Prosecution of Persons Responsible for the Most Serious Crimes under International Law Committed in the Syrian Arab Republic since March 2011". A/RES/71/248. 11 January 2017. At the time of writing, the Mechanism is functional, has issued three reports (A/72/764* of 28 February 2018, A/73/295 of 3 August 2018, and A/73/741 of 13 February 2019), and is beginning to work on case files including regarding $\mathrm{CW}$ uses. The mechanism is authorized to share evidence it collects and preserves with national prosecution services.

73 Partnership against Impunity for the Use of Chemical Weapons. 2019. "Sanctions List". 2019. https://www.noimpunitychemicalweapons.org/-en-.html 
attacks in Salisbury in March 2018, ${ }^{74}$ prompted the United Kingdom to call for the creation of a new mechanism under the CWC.

After an intensive diplomatic campaign, the Fourth Special Session of the Conference was convened in June 2018. It adopted by vote decision C-SS-4/Dec.3, ${ }^{75}$ which tasked the Secretariat to, among other things, investigate responsibility for CW attacks in the Syrian conflict, and to authorize the Director-General to provide technical expertise to States Parties, upon request, to identify perpetrators, organizers, sponsors or actors otherwise involved in the use of toxic chemicals as weapons.

The adoption of this decision by majority vote was an indication that the OPCW membership is divided on it. This division resurfaced during the subsequent Conference annual Session in autumn 2018, in the context of deciding on the 2019 programme and budget, which included provisions for a unit to implement the new mechanism, the Investigation and Identification Team (IIT). ${ }^{76}$ Division also surfaced during the Fourth Review Conference and, together with references to information gaps regarding the Syrian declaration and to the Salisbury incident, was among the reasons why the Review Conference was unable to agree on a Final Document. ${ }^{77}$

The decisions concerning the attribution mechanism are legally binding. However, some OPCW Member States maintain that the establishment of the new attribution mechanism was effectively an amendment to the Convention. ${ }^{78}$ It has also been suggested that the

${ }^{74}$ For details see Trapp, Ralf. 2018. "Novichok, the Skripal Affair and the Chemical Weapons Convention". Spiez Laboratory Annual Report 2018. pp. 4-8. www.labor-spiez.ch. An earlier, extended version was published in German: Trapp, Ralf. 2018. "Novičok, Die Skripal Affäre Und Das Chemiewaffenübereinkommen". SIRIUS - Zeitschrift Für Strategische Analysen 2(3): 219-38. https://doi.org/10.1515/sirius-2018-3002. This earlier publication also discusses the options that the United Kingdom had with regard to pursuing the matter-from bilateral attempts to clarification procedures in the Council, to approaches outside the CWC. As it was, the United Kingdom choose to pursue the issue as a national criminal investigation, demanded clarification from the Russian Federation in ways that were not consistent with the provisions of article IX of the CWC, requested technical assistance by the Technical Secretariat to confirm key findings of its investigation (in particular the identity of the agent), and kept the OPCW informed about its progress and conclusions. It is worth noting that the underlying non-compliance issue related to an undeclared part of the Russian CWC programme was alluded to by the United Kingdom in official statements, but never formally pursued as a non-compliance matter in the OPCW.

75 This received 82 votes in favour and 24 against out of a total of 152 States Parties attending. See OPCW Conference of the States Parties. 2018. "Addressing the Threat from Chemical Weapons". C-SS-4/3, 27 June 2018. https://www.opcw.org/sites/default/files/documents/CSP/C-SS-4/en/css4dec3 e .doc.pdf.

${ }^{76}$ This included draft decisions and statements that challenged the results of the Fourth Special Session: a Chinese-Russia draft decision on "Preserving the Integrity of the Organisation for the Prohibition of Chemical Weapons" (C23/DEC/CRP.14) was defeated by majority vote (30 for, 82 against); Kyrgyzstan on behalf of the Collective Security Treaty Organization submitted a statement on "Strengthening the Chemical Weapons Convention and Depoliticization of the OPCW"; the Islamic Republic of Iran submitted a series of amendments to the draft Programme and Budget of the OPCW, all of which were defeated by majority vote; the programme and budget was adopted by majority vote (99 for, 27 against).

77 The Chairman of the Review Conference issued a draft Chairman's Report (RC-4/3 of 30 November 2018) which indicated the areas of disagreement; he subsequently (with the same date) issued a revision 1 that no longer did so, with reference to the principle that nothing was agreed until everything was agreed.

${ }^{78}$ For example, the Chinese-Russian draft decision expressed concerns over the integrity of the OPCW. See OPCW Conference of the States Parties. 2018. "Report of the Twenty-Third Session of the Conference of the States Parties, 
proposal of the Technical Secretariat on how to implement the attribution mechanism may be in conflict with the fundamental principles and provisions of the $\mathrm{CWC}$, and that the mechanism would impair the prerogatives of the Security Council.

How the mechanism would function in practice remains to be seen. Regarding the investigations of chemical weapons uses in Syria, the IIT mandate is limited to gathering information that is relevant to identifying the perpetrators. ${ }^{79}$ Attribution of responsibility and decisions about follow-up measures would be in the hands of the Executive Council and the Conference. The OPCW does not have a mandate to function as a tribunal under international law. Moreover, it cannot itself submit cases to the International Criminal Court. It can, of course, transfer grave cases of violation to the Security Council. Given the veto right of the Security Council's Permanent Five States (China, France, the Russian Federation, the United Kingdom and the United States), such a transfer may not lead to any further action.

Decision C-SS-4/Dec.3 does, however, authorize the Technical Secretariat to preserve such information and provide it to the IIIM as well as other relevant investigatory entities established under United Nations auspices. ${ }^{80}$ The IIIM has both an investigative mandate and authority to share evidence with national prosecution services upon request. In other words, the results of OPCW IIT investigations could be brought as evidence into criminal prosecutions of CW use cases, through the IIIM, in circumstances where States claim jurisdiction over such cases.

The Fourth Special Session decision and the establishment of the IIT add a dimension to OPCW work that goes beyond the traditional understanding of how disarmament treaties and their implementing organizations manage cases of non-compliance. This has already resulted in political tensions among States Parties, and it is likely to lead to legal uncertainties and controversies in the future. It remains to be seen how the OPCW will manage these challenges.

\subsection{OPERATIONAL ASPECTS-GENERAL ISSUES AND ROUTINE OPERATIONS}

The CWC routine verification system also provides the backbone for non-routine, investigative fact-finding operations. Key components of the CWC routine verification system are outlined in figure 3 .

19, 20 and 29 November 2018". C-23/5, 29 November 2018.

https://www.opcw.org/sites/default/files/documents/2018/11/c2305\%28e\%29.pdf. para. 8.13-8.16

${ }^{79}$ OPCW Conference of the States Parties. 2018. "Addressing the Threat from Chemical Weapons Use". C-SS-4/Dec.3, https://www.opcw.org/sites/default/files/documents/CSP/C-SS-4/en/css4dec3 e .doc.pdf. para. 10.

${ }^{80} \mathrm{lbid}$. para. 12. The latter would include the Commission of Inquiry for Syria that has been set up under the Human Rights Council to investigate human rights violation in the Syrian armed conflict. 


\section{Components of the CWC routine verification system}

- A corps of experienced inspectors with a mix of competencies that match the different types of facilities liable to receive inspections

- Operational procedures, training/exercises, and quality assurance procedures that ensures consistent, competent and effective inspection conduct

- A competent planning and operations centre that has supported more than 7,000 on-site inspections since entry into force

- Inspection equipment that supports the different inspection tasks, managed by an efficient equipment store

- A central OPCW laboratory that supports field missions, maintains the OPCW Central Analytical Database, develops and validates analytical procedures, and manages the OPCW's Official Proficiency Tests

- Two networks of OPCW Designated Laboratories for the conduct of off-site analysis, one for environmental samples and the second for biological (biomedical) samples; work on a designation system for toxin analysis has begun

- The planned conversion of the Central OPCW Laboratory into an OPCW Centre for Chemistry and Technology

\section{Components of the CWC routine verification system}

This system has worked well for routine inspections, and successive Review Conferences have characterized it as dependable, effective and important for implementing the CWC. Adaptations in the form of new types of inspection equipment, expansion of the OPCW Central Analytical Database, or amendments of the Schedules of Chemicals that guide routine verification measures have been slow. ${ }^{81}$ However, procedures for adaptation exist and some progress has been made in using them more regularly when advances in science and technology so require or when they offer new solutions. The SAB has regularly reviewed scientific and technical aspects of this verification machinery, and prepared recommendations for improvements.

Non-routine inspections-investigations of alleged CW use and challenge inspectionsconsumed a large amount of CWC negotiation time in the Conference on Disarmament. These inspections also take up a significant share of the treaty text. However, they have never been invoked. This had long been a concern, not merely in political and legal terms but also

\footnotetext{
${ }^{81}$ A first amendment of the Schedules has only recently been initiated after the use of Novichok agents in Salisbury; the amendment process is ongoing.
} 
with regard to whether the routine verification machinery would function as required when utilized in non-routine circumstances. When the Syrian conflict began and first reports about possible uses of chemical weapons appeared in public, this question became pressing, and answers needed to be found urgently.

\subsection{OPERATIONAL ASPECTS-AD-HOC MISSIONS}

The first mission that the OPCW supported in Syria was the Secretary-General's Mechanism for Investigation of Alleged Use of Chemical and Biological Weapons investigation of uses of chemical weapons in Syria in 2013, including the Sarin attack on Ghouta. Although the OPCW was not in a lead role, ${ }^{82}$ many of the procedures were copied across from OPCW procedures. ${ }^{83}$ Adaptations were made when necessary, but the basic approach towards ensuring high standards in the science applied, in quality assurance and safety/protection, and where possible the reliance on tested standard operating procedures and work instructions, was retained.

The first Syria mission in which the OPCW was firmly in control was the Joint Mission established in follow-up to resolution 2118 (2013). ${ }^{84}$ Subsequent missions-the FFM and the Declaration Assessment Team-were 'pure' OPCW missions, while the JIM was again a mission established by the Security Council and supported by a contingent of OPCW staff seconded to it.

The Secretary-General's Mechanism mission of 2013 highlighted certain critical issues for the conduct of investigation missions under non-permissive circumstances, which would also be important in subsequent contingency missions. A formal lessons-learned process guided by the Office for Disarmament Affairs extracted several lessons related to the activation of the mechanism, the framing of the mission's mandate, and the establishment of the mission with all its essential components. ${ }^{85}$

A subsequent OPCW lessons-learned exercise looked specifically at the experience from the Joint Mission. ${ }^{86}$ With regard to operational issues, this report highlighted several issues that

82 This was a United Nations mission led by Åke Sellström of Sweden who directly reported to the Secretary-General. Both the OPCW and the WHO made personnel available to the mission. The OPCW's participation was decided on the basis of para. 27 of part XI of the CWC Verification Annex, and the UN-OPCW Relationship Agreement.

${ }^{83}$ Including such critical issues as ensuring a strict chain of custody, managing the vast amount of data and evidence collected through interviews, medical examinations, site inspections and sample analysis, and reporting (daily reports as well as the reporting of analysis results by Designated Laboratories).

${ }^{84}$ The Secretary-General appointed Sigrid Kaag as Leader of the overall Mission, and the United Nations took charge of political and security matters as well as in-country logistics; the technical work on the ground was under the control of the OPCW Director-General and his team.

85 UNODA. 2015. "The Secretary-General's Mechanism for Investigation of Alleged Use of Chemical, Bacteriological (Biological) or Toxin Weapons - A Lessons-Learned Exercise for the United Nations Mission in the Syrian Arab Republic". https://www.un.org/disarmament/publications/more/syrian-II-report/.

${ }^{86}$ Trapp, Ralf. 2015. "Lessons Learned from the OPCW Mission in Syria". https://www.opcw.org/fileadmin/OPCW/PDF/Lessons learned from the OPCW Mission in Syria.pdf. 
posed challenges, and that were successfully managed by the OPCW. These are illustrated in figure 4.

\section{Joint Mission operational lessons-learned}

- The importance of the human factor including strong leadership at the strategic level as well as in the field, effective teamwork, and plain hard work

- The ability to resolve legal and political issues as they emerge (which requires adaptability as well as intelligent/responsive legal support)

- Working outside of routine structures, under the direct leadership of the Director-General, with Core Group members selected based on their particular competence and experience irrespective of their position in the Technical Secretariat

- Setting up of a field mission for coordination of OPCW teams and with United Nations entities (in particular entities working locally)

- Working with a small in-country footprint by using just-intime and on-demand concepts for team deployments, to minimize security and safety risks

- Systems to manage and control information flows and content, to protect information and operational confidentiality, manage information-sharing, and enable proper analysis, transfer, storage and protection of data

- Systems and procedures to assess and manage safety and security risks during field deployments and operations, in close cooperation with the Department of Safety and Security of the United Nations

- Principles, procedures and tools that ensure the verification standard required under the CWC; this often required adaptation of routine methodologies to the special circumstances in the Syrian conflict

- Fast-track procurement of certain types of equipment that were not available and required adaptations of the OPCW procurement system and procedures

- New inspection techniques such as the use of satellite imagery, open-source monitoring, or remote inspection 
techniques using GPS-controlled tamper-proof video

cameras and remote monitoring systems

\section{FIGURE 4 Joint Mission operational lessons-learned}

Overall, it became clear that the OPCW mission needed to integrate with other partners, in particular United Nations entities operating in the field. It relied on their local expertise, knowledge of actors, understanding of the security context, and resources for transport, supplies, translation and more. ${ }^{87}$ Additionally, certain OPCW administrative systems needed to be adapted to the special demands, the complexities involved, and the time pressure.

This and subsequent reviews of OPCW operations in the region have shown that the OPCW very quickly learned to adapt its systems to manage contingencies. FFM and the Declaration Assessment Team, as well as the JIM, benefited enormously from the practical experience gathered during the Joint Mission. At the same time, adapting routine management structures to the needs of contingency operations was not always easy and increased the workload not only of those involved directly in the operation, but also of units in the Technical Secretariat that indirectly supported the operation.

The different ad hoc mechanisms implemented in the Syrian context have shown the OPCW's ability to adopt flexible and pragmatic solutions when the normal mechanisms of the CWC are considered politically too sensitive. As has been noted, there is a penalty, however, for using ad hoc procedures:

[W] hile the rules of the Convention have been painstakingly negotiated and form part of the Convention, the rules of engagement for ad hoc mechanisms are open to interpretation ... . The price to be paid for flexibility and adaptability is that the standards of proof are not agreed, that procedures must be negotiated with the States Parties most concerned or involved, and that conclusions are open to challenge. There is therefore perhaps a limit as to how much the OPCW can rely on ad hoc arrangements in lieu of using the compliance assurance mechanisms of the Convention itself. ${ }^{88}$

Reliance on ad hoc mechanisms can create vulnerabilities for the Technical Secretariat and force it into a position where it has to defend its technical methods and conclusions against criticism by governments that have a strong interest in the case under investigation. ${ }^{89}$

\footnotetext{
${ }^{87}$ For a discussion of these and other challenges see also: Trapp, R. 2018. "The Future Chemical Weapons ConventionOut-Dated Model or CWC 2.0". In Preventing Chemical Weapons: Arms Control and Disarmament as the Sciences Converge, edited by Michael Crowley, Malcolm Dando, and Lijun Shang. https://doi.org/10.1039/978178801009200475. pp. 477-494.

${ }^{88}$ Crowley, Michael, Ralf Trapp, Malcolm Dando, and Lijun Shang. 2018. "Conclusions and Recommendations". In Preventing Chemical Weapons, edited by Michael Crowley, Malcolm Dando, and Lijun Shang. https://doi.org/10.1039/9781788010092-00619p. p. 631.

${ }^{89}$ A recent example were the challenges brought by the Syrian Arab Republic and the Russian Federation against the report of the FFM on its investigation of the alleged chlorine attack in Douma on 7 April 2018. These included questions about a range of detailed technical and procedural details, statements that some of the findings were
} 
Finally, there remain challenges to maintaining long-run operational expertise and capacity for contingency operations, including investigations of non-compliance concerns. Developing sound operational concepts for the new attribution mechanism (the IIT) will call for the lessons learned by the JIM and other bodies to be taken account of. Political will is required to ensure that the necessary resources for such investigation are available. The OPCW already needed to adapt the implementation of its tenure policy and accept the rehiring of former inspectors who had served their full-service time with the OPCW and would normally not be eligible to re-join the Technical Secretariat. And of course, funding will be essential: special missions such as in the Syrian context have been financed, as a rule, through trust funds. This requires continuing political support by States Parties and their willingness to make extra-budgetary funds available. To ensure stability and continuity, however, some of the funding required should become part of the regular budget of the OPCW.

probabilistic or based on assumptions and hence open to being called into question, that there was no evidence to substantiate the number or victims reported, that the evidence provided did not support the FFM conclusion that the gas cylinders had been dropped from an aircraft, questions on the selection of Designated Laboratories that conducted the off-site analysis and of witnesses interviewed by the FFM, and accusations about procedures not having been in line with the CWC and double standards being used by the FFM. For details and for the response by the Technical Secretariat see OPCW Technical Secretariat. 2019. "Note by the Technical Secretariat: Update on the OPCW Fact-Finding Mission in Syria". S/1755/2019, 21 May 2019.

https://www.opcw.org/sites/default/files/documents/2019/05/s-1755-2019.pdf. 


\section{ADVANCES IN SCIENCE AND TECHNOLOGY}

Advances in science and technology affect "CWC compliance management in several ways, as illustrated below in figure $5 .{ }^{90}$ The SAB provides advice on advances in science and technology to the OPCW. It was established first in 1998, and has evolved since its foundation in terms of membership (an increase from 20 to 25 members), scope of activities (with comprehensive reviews of developments in science and technology and thematic reviews on such issues as verification, convergence, and investigative sciences), and work methodology (with a stronger reliance today on informal work between formal sessions, and a diversity of temporary working groups). ${ }^{91}$

Effects of
advances in
science and
technology
on CWC
compliance

- Advances offer new solutions for the conduct of verification activities (new inspection methods and equipment, new tools and systems for information analysis)

- Technological and structural change in the chemical industry is changing the implementation environment of the CWC; this may require adaptation of the routine industry verification systems, as well as new skills and competencies of inspectors

- OPCW working with the science and technology community as well as industry can help raise awareness of the CWC norms and requirements, and support the adoption of self-regulatory governance mechanisms to ensure 'deep' compliance

\footnotetext{
${ }^{90}$ For a detailed discussion see Trapp, R. 2018. "Convergence of Chemistry and Biology, and Nanotechnology". In Preventing Chemical Weapons: Arms Control and Disarmament as the Sciences Converge, edited by Michael Crowley, Malcolm Dando, and Lijun Shang. https://doi.org/10.1039/9781788010092-00191. pp. 193-227.

91 This is supported by the Technical Secretariat's science adviser-a position that was added to the Secretariat staffing table following a recommendation of the advisory panel appointed in 2011 by the Director-General to provide recommendations on future OPCW priorities. See OPCW Technical Secretariat. 2011. "Note by the Director General Report of the Advisory Panel on Future Priorities of the Organisation for the Prohibition of Chemical Weapons". S/951/2011, https://www.opcw.org/sites/default/files/documents/PDF/Advisory Group report s-951-2011_e .pdf. See in particular paras. $71-80$.
} 
Also, civil society plays an increasing role in monitoring and evaluating advances in science and technology, as well as other developments that are of relevance to compliance assessments. The OPCW increasingly recognizes the importance of engaging with civil society, for example regarding open-source monitoring, and the SAB has been both an advocate and conduit for stronger engagement in this respect. $A$ key development was the creation of a close working relationship between the SAB and International Union of Pure and Applied Chemistry, in the run up to the First Review Conference.

In sum, the OPCW has developed and continues to expand its capacity within the Technical Secretariat to monitor and evaluate advances in science and technology, use science and technology for the benefit of fact finding, and provide technical assistance to States Parties. A robust advisory structure is in place within the Technical Secretariat and through the SAB and the Advisory Board on Education and Outreach, and the OPCW has developed strong partnerships with other actors such as the International Council of Chemical Associations and the International Union of Pure and Applied Chemistry. The future Science and Technology Centre will boost significantly the scientific capacity of the OPCW and will have a significant effect on its capacity to use science and technology for compliance management, and to identify new risks early and respond to them appropriately. 


\section{COMPLIANCE ENFORCEMENT AND THE CWC}

Article XII of the CWC, which deals with redressing a situation of non-compliance, has never been invoked, despite the number of confirmed cases of chemical weapons use in the Syrian conflict which the JIM has attributed to the Syrian government. The possibility of invoking article XII came up briefly in discussions about how to manage the delays in the destruction of chemical weapons stockpiles of the two main possessors in the run-up to the final extended destruction deadline. However, this was immediately discarded as politically unwise and counterproductive.

Prior to the cases of confirmed use of chemical weapons in the Syrian conflict and the assassination attempt on the Skripals using a Novichok agent in the Untied Kingdom, compliance concerns were as a general rule addressed either through bilateral procedures, or on the basis of the provisions of article VIII without a formal link to the provisions under article XII.

These cooperative procedures have worked reasonably well, albeit in some cases rather slowly. They helped maintain a cooperative environment which enabled the resolution of compliance concerns, opened channels of assistance to States Parties, and created political conditions that encouraged States to take steps to comply fully with their obligations.

After the Syrian Arab Republic became a State Party, cooperative compliance became more problematic. Despite official proclamations to the contrary, the Syrian Arab Republic had not joined the CWC of its own free accord. It was, however, not a defeated State that had no choice but to accept the rules and obligations imposed on it. Cooperation of the Syrian government appeared to be forthcoming during the early months of implementation of the Executive Council decision to eliminate Syrian chemical weapons. However, doubts emerged early on about Syrian compliance with the obligation to submit a full, complete and accurate declaration of its CW stockpile and production capacity as the baseline for evaluating its compliance. In addition, the progress made by the Declaration Assessment Team to reconstruct the history of the Syrian CW programme in order to identify gaps and omissions in the Syrian declaration was beginning to dwindle over time. As time passed, the FFM and the JIM experienced a lack of cooperation and increasing hostility from Syrian authorities.

When the Russian Federation got involved directly in the Syrian conflict, putting forces on the ground and embedding military personnel in the Syrian armed forces, CWC compliance management became more complex. While that does not (and did not) preclude the adoption of OPCW resolutions condemning the use of CW in Syria, unity in the Executive Council and the Conference began to break apart, in particular regarding attribution and the measures needed to re-establish full compliance. 
It seems, at this moment, that States that wish to pursue non-compliance matters related to chemical weapon uses in the Syrian conflict, the United Kingdom and Malaysia have shown a preference for dealing with the OPCW at a political level. In parallel, enforcement steps are being pursued at the national level and are typically directed at individual perpetrators. ${ }^{92}$ For example, Germany and France have reportedly opened criminal investigation cases that could lead to prosecution of individuals responsible for certain CW attacks in the Syrian conflict. The United Kingdom, too, continues to pursue its criminal investigation of the Skripal case.

There is a risk that these efforts confuse the issues of treaty compliance and criminal responsibility. The former is a matter of State responsibility and collective compliance management, the latter of criminal responsibility, which relates to individuals and legal entities, but not usually States. It remains to be seen what the effect of these steps will be on State compliance.

The current obstacles towards enforcing the norm against the use of CW at the State level raise some fundamental questions about the functioning of the international system. In international law, States are, at the same time, the source of the law, the prosecutor of violations, the judge, the executioner, and (if in violation of norms) the culprit. Enforcing international law requires a degree of cooperation and acceptance of generally agreed rules by all States concerned. Unity in the Security Council is key to creating conditions that would ensure such cooperation. When this willingness to cooperate and apply common rules is lacking, narrow national interest and geopolitical considerations can become predominant and collectively enforcing the law becomes increasingly difficult.

92 One exception is the like-minded collective of States working in the International Partnership Against Impunity for the Use of Chemical Weapons. This partnership applies sanctions against individuals and entities that have been identified as being involved in or supported preparations for the use of chemical weapons and toxic substances. The sanctions list of the partnership is available at https://www.noimpunitychemicalweapons.org. 


\section{CONCLUSIONS}

The CWC establishes a sophisticated, multifaceted legal and procedural framework for compliance assessments and decision-making in cases of noncompliance. It stipulates a clear delineation of responsibilities of the different organs of the OPCW (Director-General, Technical Secretariat, Council and Conference all have their particular role in this system) to assess and manage compliance, which includes fact-finding, assessments at technical and legal/political levels, decisions on measures to take to restore full compliance including sanctions, and options for taking grave non-compliance cases to the General Assembly or Security Council. This system is essentially cooperative and aims at re-establishing compliance as soon as possible.

Compliance management under the CWC builds on objective and scientifically sound fact finding. For this, the OPCW has developed excellent technical, legal and political mechanisms, methods and tools, both in-house and through States Parties. These compliance management mechanisms have worked well for dealing with 'technical' noncompliance issues (i.e., non-implementation of certain CWC requirements other that those stipulated in article I). Even the delay of CW destruction past the final extended destruction deadline was resolved in a cooperative and pragmatic manner, despite the serious political and legal concerns that some parties had raised in respect to a failure to implement one of the fundamental obligations of the CWC.

The OPCW has successfully managed a range of situations where States Parties had fallen short of implementing CWC requirements, ranging from informal clarifications to technical assistance offered by the Technical Secretariat.

The use of Sarin and chlorine in the Syrian conflict has changed things. Overlaid by geopolitical interests, this chemical weapons use and the Novichok poisoning of the Skripals in Salisbury resulted in a polarization in the OPCW policymaking organs with decisions increasingly taken along lines of political allegiances and a growing controversy about the wisdom and legality of attribution investigations. The institutional, reputational, legal and political implications for the CWC and the OPCW are yet to be fully understood.

This analysis suggests that there is need for a clear separation between the management of State compliance with treaty undertakings (which may include sanctions under the CWC), and the response to criminal acts committed by individuals or legal entities. The ability of the OPCW to investigate CWC violations and collect evidence to this end, including with regard to the responsibility for such acts, must not be questioned. But when it comes to responses that reach beyond CWC sanctions (such as military sanctions or the prosecution of individuals), other international bodies are called upon to act. The Security Council bears a particular responsibility in this regard, given its responsibilities and powers under the Charter of the United Nations as well as its relationship to the International Criminal Court. 
For the Security Council to meet this responsibility, a return to common purpose in safeguarding international peace and security is needed. 


\section{ANNEX 1:}

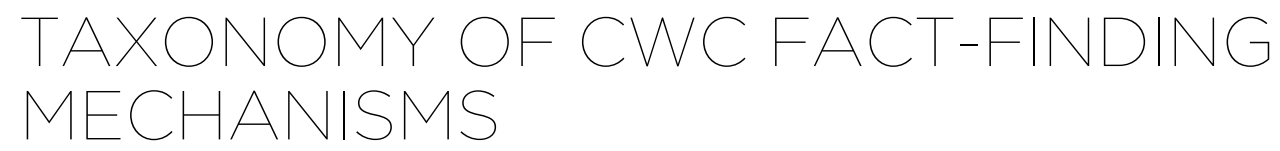

\section{ROUTINE VERIFICATION MEASURES}

- Systematic verification of chemical weapons (CW) as well as chemical weapons production facilities as well as their destruction/elimination, which principally involves:

- Declarations by States Parties of CW facilities and their inventories in terms of agents, weapons/storage containers, and CW production/filling equipment

- Initial and subsequent inspections of the declared CW storage and production facilities to verify the declared inventories and other information, and to safeguard declared items until their destruction

- Verification of the transfers of CW items to CW destruction facilities, upon arrival at the destruction site

- Verification by permanent monitoring by inspectors and/or monitoring systems of all items and operations related to the destruction of CW and the destruction or conversion for permitted purposes of CW production facilities (in case of conversion, the converted facilities remain subject to systematic inspection for a minimum of 10 years)

- Confirmation of the declared CW agent fills during the destruction operations

- Systematic data reconciliation between initial declarations, subsequent declaration amendments, inspection results including inventory controls, destruction operations reports, data gathered during destruction monitoring by inspectors unto all destruction/conversion operations at a given facility have been completed

- Certification of completion of destruction/conversion for a given facility

- Systematic verification Schedule 1 facilities:

- Declaration by States Parties of any Schedule 1 facilities they have or plan to put into operation

- Initial inspection of declared facilities to confirm declared data and gather information as a basis for risk assessment by the Technical Secretariat and for developing the facility agreement for subsequent inspections

- Systematic subsequent inspections based on Technical Secretariat risk assessment and guidance by the policymaking organs (budget allocation for inspection conduct) to confirm declared data, and to ensure that the facility is operating and configured according to $\mathrm{CWC}$ requirements

- Routine verification of industrial facilities (Schedules 2 and 3, other chemical production facilities): 
- Declaration of Schedule 2 production, processing and consumption facilities; Schedule 3 production facilities, and other chemical production facilities producing unscheduled discrete organic chemicals, above declaration thresholds set out in the Verification Annex

- On-site inspection of Schedule 2/3 facilities and other chemical production facilities above the verification threshold set out in the Verification Annex:

- Verification of declared data (including amounts or production ranges, as applicable) and of the non-production of chemicals for chemical weapons purposes

- Verification that activities and features at the inspected facility are consistent with CWC requirements

- Assessments of the risk posed to the object and purpose of the CWC based on declared data and inspection findings, to be taken into account of future inspection conduct

\section{NON-ROUTINE VERIFICATION MEASURES}

- Investigations of alleged use:

- Triggered either by a State Party threatened by or victim of CW attack (art. XI), or as a challenge inspection (art. IX)

- Collection of factual information on-site (sites of the alleged use, hospitals and refugee camps, other relevant locations) to investigate whether chemical weapons have been use, and of information that might help identifying the origin of such weapons

- With reference to article $X$, collection of information to identify assistance needs of the State Party threatened or attacked with CW

- Challenge inspections (Cl):

- Triggered by a State Party to verify concerns about possible non-compliance, can be launched in respect to any location or facility of another State Party (including undeclared facilities)

- The Executive Council can abort the implementation of a $\mathrm{Cl}$ by a three-fourths majority vote within 24 hours of receipt of the request

- The inspected State Party (ISP) can delay access (up to 120 hours after receipt of the inspection notification), and manage access at the requested site, to protect confidential information unrelated to $\mathrm{CW}$

- Inspectors may collect factual information related to the $\mathrm{Cl}$ request which may include testimony, samples for on-site or off-site analysis, other physical evidence, documentary evidence, and photographs; they also asses the degree of cooperation by the ISP 
- The final $\mathrm{Cl}$ report and any comments by the ISP are submitted to the Executive Council and all States Parties; the Executive Council will consider (a) whether non-compliance has occurred, (b) whether the request for the $\mathrm{Cl}$ has been within the scope of the $\mathrm{CWC}$, and (c) whether the right to request a $\mathrm{Cl}$ had been abused; the Executive Council shall take any measures necessary to redress the situation and ensure compliance-in case of abuse it shall examine whether the requesting State Party should bear any of the financial implications of the $\mathrm{Cl}$

- In case of confirmed non-compliance, the CWC measures related to redressing a situation and re-establishing compliance would apply as appropriate in the particular case.

- IIT (established in follow-up to the Fourth Special Session of the Conference), mandated to undertake investigations in Syria to gather information that would allow attribution of responsibility for confirmed CW uses, and to provide technical expertise upon request to States Parties in their national investigations of CW uses

\section{CLARIFICATION PROCEDURES}

- Bilateral clarification procedures:

- General obligation of States Parties to consult and cooperate among themselves, or through the OPCW, or through other appropriate international procedures (such as the United Nations)

- Bilateral clarifications with reference to art. IX.2; response within 10 days; options to arrange for bilateral inspections by mutual consent or to use other bilateral clarification mechanisms

- Clarification procedures involving the Executive Council:

- Request to the Executive Council to assist in a clarification attempt:

- By providing information available to it

- By obtaining clarification from the party that has caused the noncompliance concern

- This may include the establishment by the Director-General of a group of experts from the Technical Secretariat and external sources to examine all available information and submit a factual report on its findings to the Executive Council

- Request the Executive Council to clarify a situation that has been considered ambiguous or has given rise to a non-compliance concern regarding the State Party making the request 


\section{AD HOC MECHANISMS}

Established by the Director-General, under their general authority given to them by the CWC, with the consent of the Syrian government, and endorsed by the Executive Council:

- FFM to investigate cases of allegations of the use of CW/toxic chemicals in the Syrian armed conflict

- Declaration Assessment Team to clarify gaps and inconsistency in the Syrian CW declaration under the CWC 


\section{ANNEX 2:}

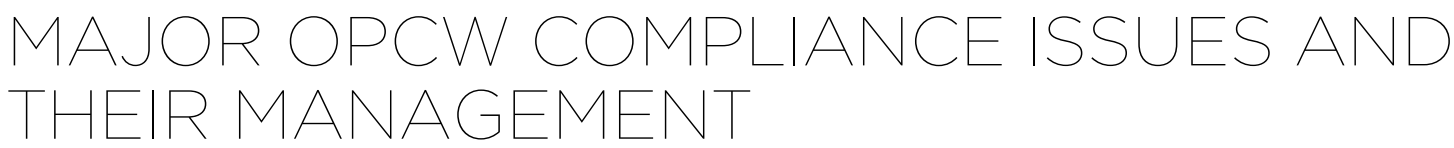

Obligation / Requirement
Submission of initial declarations under art. III,
IV, V and VI
- $\quad$ Failure to submit an initial declaration
altogether
- $\quad$ Failure to submit essential parts of an
initial declaration (e.g., absence of US
industry declaration in first years after
entry-into-force because of delay in
enacting legislation)

Enactment of national legislation to implement the CWC

- $\quad$ Failure to enact new or adapt existing legislation (art. VII.1)

- Incomplete regulatory coverage of CWC requirements (art. VII.1, art. VI.2)

- Failure to inform the OPCW of the legislative and administrative measures taken (art. VII.5)

- $\quad$ Requirement to review existing export control measures to render them consistent with the CWC (art. XI.2(e))

\section{Action Taken by the OPCW}

Technical Secretariat reminders during the early months after entry-into-force

Director-General initiative to encourage and facilitate submission of initial declarations

Regular reporting to annual Conference of States Parties sessions

First Review Conference and subsequent art. VII action plan

Follow-up measures to art. VII action plan

Technical Secretariat contacts to delegations and National Authorities to offer support

Technical assistance (commentaries on draft legislation, legislation drafting support at OPCW and on-site)

Legislation questionnaires

Legislation tool kit

First Review Conference and subsequent art. VII action plan

Follow-up measures to art. VII action plan

Legislation workshops (national, regional, OPCW-wide)

High-level visits and work with parliamentarians

Regular status reports by the Director-General on art. VII implementation to annual Conference of States Parties sessions and Review Conferences

Regional and national seminars and workshops

Training for National Authority personnel

First Review Conference and subsequent art. VII action plan

Follow-up measures to art. VII action plan

Regular status reports by the Director-General on art. VII implementation to annual Conference of States Parties sessions and Review Conferences 


\begin{tabular}{|c|c|}
\hline Obligation / Requirement & Action Taken by the OPCW \\
\hline $\begin{array}{l}\text { Put in place standing arrangements to support } \\
\text { inspection conduct (Verification Annex, pt. II): } \\
\text { - Designation of points of entry } \\
\text { - } \quad \text { Two-year multiple entry visa issuance } \\
\text { to inspectors } \\
\text { - Standing diplomatic clearance number } \\
\text { - of inspection flights } \\
\text { - Measures to enable use of inspection } \\
\text { - } \text { equipment } \\
\text { Radio frequency assignment for } \\
\text { inspection teams }\end{array}$ & $\begin{array}{l}\text { Regular status reporting to annual Conference of States } \\
\text { Parties sessions } \\
\text { Background papers and analyses to First and subsequent } \\
\text { Review Conferences } \\
\text { Notes Verbales campaign and visits by the Technical } \\
\text { Secretariat to alert National Authorities to gaps and } \\
\text { actions needed }\end{array}$ \\
\hline $\begin{array}{l}\text { Submit annual declarations and reports under } \\
\text { articles III, IV and V }\end{array}$ & $\begin{array}{l}\text { Regular reporting of status and issues to annual sessions } \\
\text { of the Conference of States Parties } \\
\text { Reports by the Technical Secretariat to First and } \\
\text { subsequent Review Conferences } \\
\text { Training for National Authorities }\end{array}$ \\
\hline Submit annual declarations under article VI & $\begin{array}{l}\text { Regular reporting by the Technical Secretariat to annual } \\
\text { Conference of States Parties sessions } \\
\text { Reports by the Technical Secretariat to } 1^{\text {st }} \text { and } \\
\text { subsequent Review Conferences } \\
\text { Electronic Declaration Submission tool }\end{array}$ \\
\hline $\begin{array}{l}\text { Submit information annually on national } \\
\text { programme for protective purposes }\end{array}$ & $\begin{array}{l}\text { Regular reporting by the Technical Secretariat to annual } \\
\text { Conference of States Parties sessions } \\
\text { Reports by the Technical Secretariat to First and } \\
\text { subsequent Review Conferences }\end{array}$ \\
\hline $\begin{array}{l}\text { Elect measures to provide assistance in } \\
\text { response to a call for assistance from the OPCW } \\
\text { (art. X.7) }\end{array}$ & $\begin{array}{l}\text { Regular reporting by the Technical Secretariat to annual } \\
\text { Conference of States Parties sessions } \\
\text { Reports by the Technical Secretariat to First and } \\
\text { subsequent Review Conferences }\end{array}$ \\
\hline
\end{tabular}




\begin{tabular}{|l|l|}
\hline Obligation / Requirement & Action Taken by the OPCW \\
\hline & $\begin{array}{l}\text { Informal approaches by the Technical Secretariat to } \\
\text { States Parties that requested evaluation of facilities } \\
\text { potentially declarable } \\
\text { Reporting by the Technical Secretariat to the Executive } \\
\text { Council on issues and technical evaluation and assistance } \\
\text { visits conducted }\end{array}$ \\
$\begin{array}{l}\text { Submission of complete and accurate } \\
\text { declarations of CW stockholdings, OPCW } \\
\text { locations/findings, and of CW production } \\
\text { facilities }\end{array}$ & $\begin{array}{l}\text { Amendments by States Parties of their CW declarations } \\
\text { as additional data becomes available (encouraged by First } \\
\text { and subsequent Review Conferences) } \\
\text { Syrian context: Executive Council decision on the } \\
\text { elimination of Syrian CW including special inspection } \\
\text { mechanism in case of doubts, subsequently } \\
\text { establishment of the Declaration Assessment Team } \\
\text { (agreement by the Director-General and Syrian Arab } \\
\text { Republic, subsequently endorsed by the Executive } \\
\text { Council) }\end{array}$ \\
\hline $\begin{array}{l}\text { Prohibition to transfers chemicals, equipment } \\
\text { and technologies for the acquisition of chemical } \\
\text { weapons }\end{array}$ & $\begin{array}{l}\text { Discussion of the role of export controls at First and } \\
\text { subsequent Review Conferences } \\
\text { Inclusion of the requirement to review existing export } \\
\text { control legislation in the article VII Action Plan and } \\
\text { subsequent measures }\end{array}$ \\
\hline $\begin{array}{l}\text { Detailed reporting by the Technical Secretariat to the } \\
\text { Executive Council } \\
\text { Executive Council facilitation of a decision in case the } \\
\text { deadline was missed } \\
\text { Director-General reporting on deadline missed } \\
\text { Decision on extension of the final destruction deadline for } \\
\text { the United States, the Russian Federation and Libya } \\
\text { including reporting requirements, verification, new final } \\
\text { deadline arrangements) }\end{array}$ \\
\hline
\end{tabular}




\begin{tabular}{|l|l|}
\hline Obligation / Requirement & Action Taken by the OPCW \\
\hline \multirow{5}{*}{ Prohibition to use chemical weapons } & $\begin{array}{l}\text { Diplomatic approaches by the Director-General to States } \\
\text { Parties when CW use reports appeared in public } \\
\text { (example: the Sudan) } \\
\text { Participation in Secretary-General's Mechanism } \\
\text { investigation in Syria (Syrian Arab Republic became a } \\
\text { State Party during the period of investigation) } \\
\text { Executive Council decision on the elimination of Syrian } \\
\text { CW } \\
\text { Establishment of the FFM for the Syria conflict } \\
\text { Participation of the OPCW in the JIM } \\
\text { Considerations of use and attribution of responsibility in } \\
\text { Executive Council and Conference of States Parties } \\
\text { sessions } \\
\text { Fourth Special Session setting up attribution mechanism } \\
\text { Establishment of the IIM }\end{array}$ \\
\hline
\end{tabular}





\section{WMD COMPLIANCE \& ENFORCEMENT SERIES}

Compliance and Enforcement in WMD-related Treaties

\section{IAEA Mechanisms to Ensure Compliance with NPT Safeguards}

\section{Compliance Management under the Chemical Weapons Convention}

Compliance and Enforcement in the Biological Weapons Regime

Monitoring, verification, and compliance resolution in U.S.- Russian arms control

Compliance and Enforcement: Lessons from across WMD-related regimes 